\title{
Long-term tillage and crop rotation effects on soil quality, organic carbon, and total nitrogen
}

\author{
Laura L. Van Eerd ${ }^{1}$, Katelyn A. Congreves ${ }^{1}$, Adam Hayes ${ }^{2}$, Anne Verhallen ${ }^{2}$, and \\ David C. Hooker ${ }^{3}$ \\ ${ }^{1}$ School of Environmental Sciences, University of Guelph, Ridgetown Campus, Ridgetown, Ontario, \\ Canada NOP 2CO (e-mail: Ivaneerd@uoguelph.ca); ${ }^{2}$ Ontario Ministry of Food and Agriculture and \\ Ministry of Rural Affairs, Ridgetown, Ontario, Canada NOP 2CO; and ${ }^{3}$ Department of Plant Agriculture, \\ University of Guelph, Ridgetown Campus, Ridgetown, Ontario, Canada NOP 2 CO. \\ Received 4 October 2013, accepted 22 April 2014. Published on the web 5 May 2014.
}

Van Eerd, L. L., Congreves, K. A., Hayes, A., Verhallen, A. and Hooker, D. C. 2014. Long-term tillage and crop rotation effects on soil quality, organic carbon, and total nitrogen. Can. J. Soil Sci. 94: 303-315. Long-term studies allow for quantification of the effects of crop production practices, such as tillage and crop rotation, on soil quality and soil $\mathrm{C}$ and $\mathrm{N}$ stores. In two experiments at Ridgetown, ON, we evaluated the long-term (11 and $15 \mathrm{yr}$ ) effect of tillage system and crop rotation on soil quality via the Cornell Soil Health Assessment (CSHA) at $0-15 \mathrm{~cm}$ and soil organic C (SOC) and total N at 5-, 10-, and 20-cm increments to $120 \mathrm{~cm}$ depth. The CSHA soil quality score and SOC and total $\mathrm{N}$ were higher with no-till (NT) than fall moldboard plough with spring cultivation (conventional tillage, CT) and rotations with winter wheat [soybean-winter wheat (S-W) and soybean-winter wheat-corn (S-W-C)] compared with rotations without winter wheat. In both long-term trials, NT had ca. $21 \mathrm{Mg} \mathrm{ha}^{-1}$ more or $14 \%$ higher SOC than CT in the 0 - to 100 -cm soil profile, a trend which contrasts previous research in eastern Canada. Thus, the two long-term trial results at Ridgetown suggest that to improve soil quality and storage of $\mathrm{C}$ and $\mathrm{N}$, growers on clay loam soil in southwestern Ontario should consider adopting NT production practices and including winter wheat in the rotation.

Key words: Cornell Soil Health Assessment, continuous corn, Ridgetown, no-tillage, moldboard plow/plough tillage, soybean-winter wheat-corn crop rotations

Van Eerd, L. L., Congreves, K. A., Hayes, A., Verhallen, A. et Hooker, D. C. 2014. Incidence à long terme du travail du sol et de l'assolement sur la qualité du sol, sur sa teneur en carbone organique et sur la concentration totale d'azote. Can. J. Soil Sci. 94: 303-315. Les études de longue haleine servent à quantifier les conséquences de pratiques agricoles comme les labours et l'assolement sur la qualité du sol ainsi que sur ses réserves de carbone et d'azote. Deux expériences réalisées à Ridgetown, en Ontario, ont permis d'évaluer les répercussions à long terme (11 et $15 \mathrm{ans})$ du travail du sol et de l'assolement sur la qualité du sol à une profondeur de 0 à $15 \mathrm{~cm}$ ainsi que sur la concentration de carbone organique et celle d'azote total jusqu'à $120 \mathrm{~cm}$ de profondeur, par paliers de 5, 10 et $20 \mathrm{~cm}$. Les auteurs ont recouru pour cela à la méthode Cornell Soil Health Assessment (CSHA). La note relative à la qualité du sol établie grâce à la CSHA et la concentration de carbone organique et d'azote total étaient plus élevées pour le non-travail du sol que pour le labour automnal au versoir suivi du passage d'un cultivateur au printemps (travail classique du sol, TC), et pour les assolements incluant du blé d'hiver (soja-blé d'hiver, S-B, et soja-blé d'hiver-maïs, S-B-M) que pour ceux sans blé d'hiver. Lors des deux expériences, les parcelles non travaillées renfermaient environ $21 \mathrm{Mg}$ par hectare ou $14 \%$ de carbone organique de plus que celles soumises au TC, dans la couche de 0 à $100 \mathrm{~cm}$, tendance qui contraste avec les résultats des recherches antérieures réalisées dans l'est du Canada. Les résultats des deux essais de longue haleine réalisés à Ridgetown laissent donc croire que pour améliorer la qualité du sol et y stocker plus de $\mathrm{C}$ et de $\mathrm{N}$, ceux qui cultivent des loams argileux dans le sud-ouest de l'Ontario devraient songer à adopter des pratiques agricoles sans travail du sol et à ajouter le blé d'hiver à leurs assolements.

Mots clés: Cornell Soil Health Assessment, monoculture du maïs, Ridgetown, non-travail du sol, labours au versoir/soc, assolement soja-blé d'hiver-maïs

Maintaining and building soil quality is necessary to sustain crop yields and the competitiveness of Ontario's agricultural industry. However, it is difficult to define soil quality (Carter 2005) because soil quality encompasses the chemical, physical and biological components of a soil (Kennedy and Smith 1995; Arias et al. 2005) and relates to various agro-ecological functions of soil such as sustaining plant and animal productivity, maintaining or enhancing water and air quality and cycling of water and nutrients. Thus, soil quality indicators should integrate properties and processes inherent to the aforementioned components (Karlen et al. 2003) and should

Abbreviations: C-C, continuous corn monoculture; CSHA, Cornell Soil Health Assessment; CT, conventional tillage system; chisel-T, chisel plough tillage; NT, no-till system; S-C, soybeancorn rotation; SOC, soil organic carbon; S-S, continuous soybean monoculture; S-W, soybean-winter wheat rotation; S-W-C, soybean-winter wheat-corn rotation 
direct growers towards better soil management practices (Carter 2005).

One integrated test of soil quality is the Cornell Soil Health Assessment (CSHA), which provides growers with one number that represents overall soil health by compiling over 17 soil biological, chemical and physical parameters (Idowu et al. 2008, 2009). In addition, soil organic carbon (SOC) is a sensitive indicator of soil quality responses to agricultural management practices, such as crop rotation and tillage systems (Bolinder et al. 1999) as it influences many chemical, physical and biological parameters and is essential for agro-ecosystem functioning (Carter 2005). Both CSHA and SOC have been used to evaluate the impact of tillage and crop rotation on soil quality in long-term trials (Angers et al. 1997; Idowu et al. 2009; Stavi et al. 2012; Aziz et al. 2013; Karlen et al. 2013).

Soil characteristics and functions can be quantified in long-term agricultural experiments to assess the influence of different management practices such as tillage systems and crop rotations (Doran and Parkin 1994; Karlen et al. 2008) on overall soil health. There remains a large knowledge gap on the quantifiable effects of agricultural best management practices on the soil health parameters due to the biological complexity and lack of knowledge on their numerous interactions and roles in the soil (Arias et al. 2005). Long-term trials may serve as important tools to evaluate the impact of various management practices on crop productivity, soil quality and environmental sustainability.

In long-term trials, the effect of no-till (NT) compared to conventional tillage (CT) systems in increasing SOC at the soil surface has been well documented (see West and Post 2002; Carter 2005; Kay and VandenBygaart 2002; Angers and Eriksen-Hamel 2008). However, few longterm studies have examined deeper depths to evaluate carbon storage and fewer still have considered total $\mathrm{N}$. Gál et al. (2007) determined the need to evaluate deeper soil depths (i.e., $100 \mathrm{~cm}$ ) to accurately assess the impact of management practices on $\mathrm{C}$ and $\mathrm{N}$ storage. Moreover, most of the knowledge on SOC in eastern Canada is from continuous corn (C-C) monoculture or soybean-corn (S-C) rotation; knowledge of the impact of winter wheat in the rotation and particularly continuous soybeans (S-S) on soil quality is lacking in eastern Canada. Thus there is a need to evaluate soil quality via SOC, total $\mathrm{N}$ or an integrative assessment such as the CSHA in long-term tillage and crop rotation studies.

A strong understanding of the effect of agricultural practices on soil quality is crucial to direct management practices that prevent soil and ecosystem degradation. Two long-term studies were established at Ridgetown in 1991 and 1995. The one established in 1991 compared the effect of tillage systems [NT, CT, chisel plough tillage (chisel-T)] in a S-C rotation and the 1995-initiated study compared two tillage systems (NT and CT) in five crop rotations. The objectives of this paper were to assess the impact of tillage system and crop rotation on soil quality using the CSHA in the 0 - to $15-\mathrm{cm}$ depth and SOC and total $\mathrm{N}$ in the $0-$ to $120-\mathrm{cm}$ depth using the two trials at Ridgetown. This is the first report of the long-term impact of tillage systems and crop rotations on soil quality from the trials established at Ridgetown.

\section{MATERIALS AND METHODS}

\section{Experimental Design and Treatments}

A field trial was established during 1991, and another during 1995, at the University of Guelph Ridgetown Campus, Ridgetown, ON (lat. $42^{\circ} 26^{\prime} \mathrm{N}$, long. $81^{\circ} 53^{\prime} \mathrm{W}$ ) on an Orthic Humic Gleysol, Brookston clay loam soil. These trials will be referred to as the "1991 tillage trial" and the "1995 tillage-rotation trial". In the 1991 tillage trial, three tillage treatments were arranged in a randomized complete block design with six replicates in a S-C rotation as described by McGonigle et al. (1999). Tillage treatments were: (1) NT that had no soil disturbance except for two coulters and a trash whipper per row on the planter, (2) CT with fall moldboard plough tillage followed by two or three passes with a cultivator in the spring for seedbed preparation and (3) chisel-T of fall chisel plough tillage with similar spring cultivation as CT. The 1995 tillage and rotation trial was a split plot design with four replications. Crop rotation was the main plot factor, which included C-C, S-S, S-C, soybeanwinter wheat $(\mathrm{S}-\mathrm{W})$, and soybean-winter wheat-corn (S-W-C) and the split-plot was NT and CT tillage systems. Rotations were repeated in the experiment so that all crops within the rotation were represented in every year. In both trials, top-yielding crop cultivars were planted and the same crop cultivar was never planted for more than 2 successive years. Since 2008, soybean cultivars tolerant to cyst nematode were planted with Rhizobium inoculant applied to soybean seeds. It is unlikely that the aforementioned changes in soybean planting influenced soil quality parameters sampled in 2009 at the 0 - to $15-\mathrm{cm}$ depth.

Tillage systems were established to represent extremes in soil disturbance and intensity. Soil was not disturbed in the NT system, except during planting. Conventional and chisel-T tillage for corn and soybean consisted of moldboard plough or chisel plough, respectively, in the fall at 20-cm depth, followed by two or three passes with a cultivator at 7-cm depth in the spring for seedbed preparation. For winter wheat, CT consisted of two passes with either a cultivator or tandem disc at $7-\mathrm{cm}$ depth after soybean harvest.

McGonigle et al. (1999) described the 1991 tillage trial. In the 1995 tillage-rotation trial, recommended practices were used for N, P and K fertilizer (Ontario 2009). No starter or $\mathrm{N}$ fertilizer was applied to soybean in both trials. At corn planting, $100 \mathrm{~kg} \mathrm{ha}^{-1}$ of N-P-K starter fertilizer (6-24-24) was applied in a 5 by $5 \mathrm{~cm}$ band below and beside the corn seed in all plots. Since 2009, and according to new provincial recommendations for NT corn, $30 \mathrm{~kg} \mathrm{~N} \mathrm{ha}{ }^{-1}$ was applied as starter fertilizer across 
all $\mathrm{N}$ treatments in both tillage systems. No starter was applied to winter wheat before 2009 but $11 \mathrm{~kg} \mathrm{~N}$ ha $^{-1}$ as monoammonium phosphate was applied since 2009 with the seed at planting, according to provincial recommendations. In addition to fertilizer at planting, $120 \mathrm{~kg} \mathrm{~N}^{-1}$ of urea ammonium nitrate (28-0-0) was injected at approx. $10 \mathrm{~cm}$ depth in the centre of corn rows at the 6-8 leaf stage and to winter wheat $100 \mathrm{~kg} \mathrm{~N}^{-1}$ as calcium ammonium nitrate $(27-0-0)$ was broadcast applied in late March or early April after dormancy release.

\section{Crop Management}

Within each crop, the same planting equipment was used in all tillage systems. In both trials, corn was planted in 0.76-m-wide rows with a planter equipped with two coulters per row including the starter fertilizer opener. Trash whippers were installed on the planter in 2009 to move residue out of the row area to improve early growth. In both trials, soybean was planted with a no-till drill in 0.19-m wide rows from 1991 to 2008. Since 2009, soybean stand establishment was improved with the use of a row-unit no-till drill with 0.38 -m-wide rows. In the 1995 trial, winter wheat was planted with a no-tillage drill in 0.19-m-wide rows.

Weeds were controlled in both trials with pre-emergence and post-emergence herbicides in corn and soybean, but only post-emergent herbicides were applied in winter wheat, if needed. For corn rootworm protection, infurrow insecticides were applied at corn planting. From 1991 to 2008, corn seeds were treated with a fungicide only and no fungicide seed treatment was used for soybeans. Since 2009, both corn and soybean seeds were treated with an insecticide and fungicide. Winter wheat seeds were treated with a fungicide before planting.

\section{Soil Collection and Analysis}

Soil samples were collected in November 2006 for SOC and total $\mathrm{N}$ content determination, thus the aforementioned changes to crop production in 2009 did not influence these parameters. Three or four intact $4-\mathrm{cm}$ diameter cores were collected to $120 \mathrm{~cm}$ depth using a Giddings soil corer with tubes (Giddings Machine Company, Windsor, CO) from select plots in both trials. The cores were kept cool, and segmented into $0-5,5-10,10-15,15-20,20-30,30-40,40-50,50-60,60-$ $80,80-100$, and $100-120 \mathrm{~cm}$ sections. Cores from each plot were homogenized by depth, air dried, sieved (2 $\mathrm{mm}$ ) and analyzed for SOC (Skjemstad and Baldock 2008) and total $\mathrm{N}$ content (Rutherford et al. 2008). At each depth, an aliquot of approximately $10 \mathrm{~g}$ was oven dried to determine soil moisture content. Total $\mathrm{N}$ and SOC were calculated on an equivalent soil mass basis (Ellert and Bettany 1995; Yang and Wander 1999).

It is unlikely that changes to crop production practices in the 1995 tillage-rotation trial of crop varieties that occurred in 2008 or changes to planting equipment, fertilization, and application of pesticides that occurred in 2009 had an influence on the CSHA parameters as soil was sampled in early June 2009. From the 1995 tillagerotation trial only, soil samples for the CSHA were collected from both tillage systems in each phase of the crop rotation. The protocol from the CSHA was followed for soil sampling, processing and analysis (Gugino et al. 2007; Idowu et al. 2008). Briefly, from each sub-plot, at least 30 soil cores $(1.8 \mathrm{~cm}$ diameter from the 0 - to $15-\mathrm{cm}$ depth were collected, homogenized, and stored at $4{ }^{\circ} \mathrm{C}$ before determination of the physical, biological and chemical indicators of soil health. Root disease potential was estimated as the mean of four bean bioassays according to Abawi et al. (2004). Approximately $40 \mathrm{~g}$ of soil dried at $40^{\circ} \mathrm{C}$ was used to estimate percent water stable aggregate using a rainfall simulation method (Ogden et al. 1997). A subsample of approximately $1 \mathrm{~kg}$ was sent to an accredited laboratory in Ontario (SGS Agri-Food Laboratories Ltd., Guelph, ON) for analyses, which included: soil texture (hydrometer), pH (1:1 vol/vol method), P (Olsen bicarbonate extraction), $\mathrm{K}, \mathrm{Ca}, \mathrm{Mg}, \mathrm{Zn}, \mathrm{Mn}$ (atomic absorption via ammonium acetate extraction), cation exchange capacity (estimated based on ammonium acetate extraction and $\mathrm{pH}$ ), organic matter (loss on ignition), active carbon (permanganate oxidation), and potentially mineralizable N [7 d anaerobic incubation as described by Drinkwater et al. (1996)]. A $0.1-\mathrm{kg}$ subsample of soil that was dried at $60^{\circ} \mathrm{C}$ and sieved $(2 \mathrm{~mm}$ ) was used to determine available water capacity, which was estimated as the difference between gravimetric moisture content at field capacity $(-10 \mathrm{kPa})$ and permanent wilting point $(-1500 \mathrm{kPa})$. In November 2009, soil surface hardness was determined in the field using the mean of 10 maximum penetration resistances from a soil cone penetrometer (Dickey-John Corp., IL) at the 0 - to $15-\mathrm{cm}$ depth. To minimize variability among plots in soil moisture and to more accurately obtain soil surface hardness scores, penetrometer readings were taken in November and not in June 2009 when soil samples were collected.

Each parameter was converted to an individual indicator score and summed according to Gugino et al. (2007) and Idowu et al. (2008), but soil hardness at the 15to $45-\mathrm{cm}$ depth and $\mathrm{Fe}$ as a component of the micronutrient score were not included. Normalized to a scale of 100 , the CSHA overall score provided one number that represents overall soil health (Idowu et al. 2008, 2009), with rankings of $<40 \%$ regarded as very low, $40-55 \%$ as low, $55-70 \%$ as medium, $70-85 \%$ as high and $>85$ as very high soil health (Gugino et al. 2007).

\section{Statistical Analyses}

For all data, assumptions of analysis of variance were tested with Shapiro-Wilk normality test and homogeneity by plotting residuals of predicted by fixed effects. Soil total $\mathrm{N}$ and SOC data were subjected to analysis of variance using SAS PROC GLM (SAS Institute, Inc., version 9.3 Cary, NC), with sample depth, tillage system, crop rotation, and all two- and three-way interactions in the model. Data from the CSHA were subjected to 
analysis of variance using SAS PROC MIXED, with crop rotation and tillage system as fixed effects. There were no differences between the crop phases of each rotation (i.e., soybean-corn versus corn-soybean); therefore, data were pooled across crop phases by year. For all datasets, means were separated using the Tukey-Kramer adjustment at the 0.05 probability level.

\section{RESULTS AND DISCUSSION}

\section{Cornell Soil Health Assessment 0- to 15-cm Depth}

\section{Crop Rotation}

There was no rotation by tillage interaction $(P=0.0692$ to 0.9999 ) between any of the CSHA soil quality parameters measured at the 0 - to $15-\mathrm{cm}$ depth except for permanent wilting point $(P=0.0271$; Table 1$)$. The general lack of interaction across parameters suggests that the soil quality parameters responded similarly to crop rotation regardless of tillage system. A lack of rotation by tillage interaction was also observed with soil physical properties in a prairie loam soil (Chang and Lindwall 1992) and soil chemical properties in a silty clay loam in Indiana, USA (Gál et al. 2007). Due to the general lack of interaction in soil quality parameters, the simple effects of tillage system and crop rotation were presented separately for CSHA parameters.

At Ridgetown, the CSHA soil quality score was affected by crop rotation, as were the following CSHA parameters: aggregate stability percent, penetrometer resistance, potentially mineralizable $\mathrm{N}, \mathrm{P}$ concentration and $\mathrm{Mn}$ index $(P<0.0001$ to $0.0379 ;$ Table 2$)$. The
CSHA soil quality score was the highest with S-W, which was statistically higher than $\mathrm{C}-\mathrm{C}, \mathrm{S}-\mathrm{S}$, and $\mathrm{S}-\mathrm{C}$ rotations but S-W-C was not different from all rotations (Table 2). Thus, based on the CSHA, soil quality was higher with a higher frequency of winter wheat in the rotation, which was also reported by Andrews et al. (2004).

Analogous to CSHA score, aggregate stability was higher with S-W than C-C, S-C, and S-S, but S-W-C was not different than any rotation (Table 2). Likewise, Raimbault and Vyn (1991) observed crop rotation influenced wet aggregate stability.

Penetration resistance data differed markedly between rotations $(P<0.0001$; C-C monoculture had the highest resistance compared with those in all crop rotations, while the S-S monoculture had the lowest resistance (Table 2). Differences in penetration resistance among rotations would likely have been more extreme if readings were taken in June instead of November due to expected greater differences among rotations in soil moisture in June as opposed to November. At Ridgetown, there was $136 \mathrm{~mm}$ of rainfall in September to November 2009, which corresponds to the period of corn physiological maturity and plant senescence. Thus, one might expect any differences in soil moisture content among treatments to be minimal in November when penetrometer readings were taken.

Penetration resistance $>2 \mathrm{MPa}$ tends to impede root growth (Reynolds et al. 2002); thus, with a reading of 2.2 $\mathrm{MPa}$, corn root growth may have been impeded more in the $\mathrm{C}-\mathrm{C}$ monoculture compared with other rotations, which were $<2 \mathrm{MPa}$. In contrast to results at

Table 1. Effect of tillage system ${ }^{\mathrm{z}}$ on select soil parameters and Cornell soil health assessment (CSHA) score in 0-15 $\mathrm{cm}$ after 14 yr in a long-term experiment initiated in 1995

\begin{tabular}{|c|c|c|c|c|c|}
\hline \multirow[b]{2}{*}{ Soil parameter } & \multirow[b]{2}{*}{ Unit } & \multicolumn{2}{|c|}{ Tillage system } & \multirow[b]{2}{*}{ Tillage effect $(\operatorname{Pr}>\mathrm{F})$} & \multirow{2}{*}{$\begin{array}{l}\text { Tillage by rotation interaction } \\
\qquad(\operatorname{Pr}>\mathrm{F})\end{array}$} \\
\hline & & $\mathrm{CT}$ & NT & & \\
\hline CSHA soil quality score & $\%$ & $63.4 b$ & $67.8 a$ & 0.0035 & 0.3909 \\
\hline Root health & - & 2.22 & 2.20 & 0.8607 & 0.3141 \\
\hline Aggregate stability & $\%$ & $28.0 b$ & $46.1 a$ & $<.0001$ & 0.3384 \\
\hline Penetrometer reading & $\mathrm{MPa}$ & $1.70 b$ & $2.05 a$ & $<0.0001$ & 0.0942 \\
\hline Field capacity & $\mathrm{g} \mathrm{g}^{-1}$ & 0.375 & 0.390 & 0.1689 & 0.0932 \\
\hline Permanent wilting point & $\mathrm{g} \mathrm{g}^{-1}$ & 0.161 & 0.176 & 0.0518 & 0.0271 \\
\hline Available water capacity & $\mathrm{g} \mathrm{g}^{-1}$ & 0.215 & 0.215 & 0.9027 & 0.8563 \\
\hline $\mathrm{pH}$ & - & $6.85 a$ & $6.45 b$ & 0.0001 & 0.3853 \\
\hline Cation exchange capacity & Meq $100 \mathrm{~g}^{-1}$ & 24.4 & 24.5 & 0.9341 & 0.2293 \\
\hline Active carbon & $\mathrm{mg} \mathrm{kg}^{-1}$ & 689 & 701 & 0.1984 & 0.7081 \\
\hline Organic matter & $\%$ & $4.22 b$ & $4.61 a$ & 0.0406 & 0.5254 \\
\hline Potentially mineralizable $\mathrm{N}$ & $\mathrm{mg} \mathrm{kg}^{-1}$ & $7.65 b$ & $11.1 a$ & 0.0003 & 0.3546 \\
\hline $\mathrm{P}$ & $\mathrm{mg} \mathrm{kg}^{-1}$ & 34.0 & 37.8 & 0.0832 & 0.2515 \\
\hline $\mathrm{K}$ & $\mathrm{mg} \mathrm{kg}^{-1}$ & $183 b$ & $205 a$ & 0.0433 & 0.0692 \\
\hline $\mathrm{Ca}$ & $\mathrm{mg} \mathrm{kg}^{-1}$ & 4070 & 4030 & 0.7336 & 0.1503 \\
\hline $\mathrm{Mg}$ & $\mathrm{mg} \mathrm{kg}^{-1}$ & 227 & 248 & 0.0525 & 0.2454 \\
\hline $\mathrm{Mn}$ & $\mathrm{mg} \mathrm{kg}^{-1}$ & 35.6 & 33.2 & 0.4689 & 0.5678 \\
\hline Mn Index & - & $21.8 b$ & $24.9 a$ & 0.0041 & 0.3914 \\
\hline $\mathrm{Zn}$ & $\mathrm{mg} \mathrm{kg}^{-1}$ & $2.00 b$ & $2.26 a$ & 0.0359 & 0.4363 \\
\hline Zn Index & - & $21.4 b$ & $25.2 a$ & 0.0003 & 0.4012 \\
\hline
\end{tabular}

${ }^{\mathrm{z}} \mathrm{CT}$, conventional tillage was fall moldboard plough with spring cultivation; NT, no till system had no soil disturbance except at planting. $a, b$ For each soil health parameter, means followed by a different letter indicate significant difference according to a means comparison $(P<0.05)$. 
Table 2. Effect of crop rotation on select soil parameters and Cornell soil health assessment (CSHA) score in 0-15 $\mathrm{cm}$ after 14 yr in a long-term experiment initiated in 1995

\begin{tabular}{|c|c|c|c|c|c|c|c|c|}
\hline \multirow[b]{2}{*}{ Soil parameter } & \multirow[b]{2}{*}{ Unit } & \multicolumn{5}{|c|}{ Crop rotation } & \multirow[b]{2}{*}{$\operatorname{Pr}>F$} & \multirow[b]{2}{*}{$\begin{array}{l}\text { Bluegrass } \\
\text { fence row }\end{array}$} \\
\hline & & $\begin{array}{l}\text { Continuous } \\
\text { corn }\end{array}$ & $\begin{array}{l}\text { Soybean- } \\
\text { corn }\end{array}$ & $\begin{array}{l}\text { Continuous } \\
\text { soybean }\end{array}$ & $\begin{array}{c}\text { Soybean- } \\
\text { winter wheat }\end{array}$ & $\begin{array}{l}\text { Soybean- winter } \\
\text { wheat-corn }\end{array}$ & & \\
\hline CSHA soil quality score & $\%$ & $63.6 b$ & $63.1 b$ & $64.4 b$ & $71.2 a$ & $65.4 a b$ & 0.0056 & 75.3 \\
\hline Root health & - & 2.27 & 2.06 & 2.41 & 2.20 & 2.12 & 0.0788 & 3.0 \\
\hline Aggregate stability & $\%$ & $34.0 b$ & $34.6 b$ & $33.0 b$ & $43.2 a$ & $40.3 a b$ & 0.0379 & 69.0 \\
\hline Penetrometer reading & $\mathrm{MPa}$ & $2.20 a$ & $1.85 b$ & $1.50 c$ & $1.85 b$ & $1.99 a b$ & $<0.0001$ & $\mathrm{~N} / \mathrm{A}^{\mathrm{z}}$ \\
\hline Field capacity & $\mathrm{g} \mathrm{g}^{-1}$ & 0.382 & 0.389 & 0.359 & 0.405 & 0.379 & 0.1157 & $\mathrm{~N} / \mathrm{A}$ \\
\hline Permanent wilting point & $\mathrm{g} \mathrm{g}^{-1}$ & 0.173 & 0.177 & 0.150 & 0.178 & 0.163 & 0.1145 & $\mathrm{~N} / \mathrm{A}$ \\
\hline Available water capacity & $\mathrm{g} \mathrm{g}^{-1}$ & 0.208 & 0.213 & 0.208 & 0.227 & 0.218 & 0.1732 & $\mathrm{~N} / \mathrm{A}$ \\
\hline $\mathrm{pH}$ & - & 6.40 & 6.71 & 6.82 & 6.63 & 6.69 & 0.0782 & 6.78 \\
\hline Cation exchange capacity & Meq $100 \mathrm{~g}^{-1}$ & 24.6 & 24.7 & 24.1 & 25.4 & 23.6 & 0.7909 & 15.3 \\
\hline Active carbon & $\mathrm{mg} \mathrm{kg}^{-1}$ & 706 & 693 & 682 & 707 & 686 & 0.2668 & 693 \\
\hline Organic matter & $\%$ & 4.59 & 4.21 & 4.13 & 4.87 & 4.28 & 0.0816 & 5.9 \\
\hline $\begin{array}{l}\text { Potentially mineralizable } \\
\mathrm{N}\end{array}$ & $\mathrm{mg} \mathrm{kg}^{-1}$ & $10.4 a b$ & $7.45 b$ & $7.57 b$ & $11.1 a$ & $10.3 a b$ & 0.0229 & 22 \\
\hline $\mathrm{P}$ & $\mathrm{mg} \mathrm{kg}^{-1}$ & $44.0 a$ & $40.3 a b$ & $33.8 b c$ & $30.4 c$ & $30.9 c$ & 0.0009 & 7.0 \\
\hline $\mathrm{K}$ & $\mathrm{mg} \mathrm{kg}^{-1}$ & 202 & 202 & 172 & 210 & 183 & 0.1672 & 107 \\
\hline $\mathrm{Ca}$ & $\mathrm{mg} \mathrm{kg}^{-1}$ & 3930 & 4200 & 3820 & 4290 & 4010 & 0.1168 & 2390 \\
\hline $\mathrm{Mg}$ & $\mathrm{mg} \mathrm{kg}^{-1}$ & 234 & 236 & 227 & 265 & 226 & 0.1644 & 205 \\
\hline $\mathrm{Mn}$ & $\mathrm{mg} \mathrm{kg}^{-1}$ & 37.5 & 41.6 & 29.3 & 31.3 & 32.4 & 0.1256 & 9.5 \\
\hline Mn Index & - & $27.2 a$ & $25.0 a b$ & $20.7 b$ & $21.6 b$ & $22.2 b$ & 0.0013 & 14.6 \\
\hline Zinc & $\mathrm{mg} \mathrm{kg}^{-1}$ & 2.25 & 2.14 & 1.93 & 2.28 & 2.03 & 0.4238 & 6.45 \\
\hline Zn Index & - & 25.7 & 23 & 21.6 & 23.6 & 22.4 & 0.0907 & 41.3 \\
\hline
\end{tabular}

${ }^{\mathbf{z}}$ Not available; sample not taken.

$a-c$ For each parameter, means followed by a different letter indicate a significant difference according to a means comparison $(P<0.05)$.

Ridgetown, there was no difference in penetration resistance among rotations (C-C, C-C-S-S and C-Csmall grain undersown with red clover for $2 \mathrm{yr}$ ) at Elora in a 30-yr long-term study on a silt loam soil in the $0-20$ $\mathrm{cm}$ depth (Munkholm et al. 2013). But, in the 10- to 20$\mathrm{cm}$ depth, Munkholm et al. (2013) observed penetration resistance that was similar to Ridgetown with higher readings in $\mathrm{C}-\mathrm{C}$ than the other rotations.

Although there were no differences in soil concentrations of $\mathrm{Zn}$ and $\mathrm{Mn}$ or the $\mathrm{Zn}$ index $(P=0.0907$ to $0.4238)$, the $\mathrm{Mn}$ index was higher for $\mathrm{C}-\mathrm{C}$ than all other rotations except S-C ( $P=0.0013$; Table 2$)$. Similarly, at $\alpha=0.1, \mathrm{Zn}$ index was higher with $\mathrm{C}-\mathrm{C}$ than S-S $(P=$ 0.0907; Table 2). Zinc and $\mathrm{Mn}$ indices have been developed and driven by $\mathrm{pH}$ because the availability of $\mathrm{Zn}$ and $\mathrm{Mn}$ is dependent on $\mathrm{pH}$. Crop rotation effects for $\mathrm{Zn}$ and $\mathrm{Mn}$ indices mirrored rotation effects for $\mathrm{pH}$ $(P=0.0782)$ where $\mathrm{pH}$ was lower in C-C compared with $\mathrm{S}-\mathrm{S}$ (Table 2). The $\mathrm{Zn}$ and $\mathrm{Mn}$ index response to crop rotation can be partially explained by the frequency of corn in the rotation because more $\mathrm{N}$ fertilizer was applied to corn, which can have an acidifying effect on the soil. For instance, S-S had no N fertilizer, but C-C had yearly urea ammonium nitrate applications and thereby influenced $\mathrm{Zn}$ and $\mathrm{Mn}$ indices. The relationship between $\mathrm{N}$ fertilization, $\mathrm{pH}$, and micronutrients has been documented (Blevins et al. 1983).

Similar to $\mathrm{Mn}$ and $\mathrm{Zn}$, crop rotation had an effect on $\mathrm{P}$ and potentially mineralizable $\mathrm{N}(P=0.0009$ to 0.0229$)$ but not on $\mathrm{K}, \mathrm{Ca}$, or $\mathrm{Mg}(P=0.1168$ to 0.1672 ; Table 2$)$.
Soil $\mathrm{P}$ concentration was the highest with $\mathrm{C}-\mathrm{C}$, and greater than the S-S, S-W, and S-W-C rotations (Table 2). Considering that the crops were fertilized according to crop requirements and corn crops received more $\mathrm{P}$ fertilizer than soybeans or winter wheat, the differences in soil $\mathrm{P}$ among rotations can be primarily explained by long-term fertilizer management because the trend in $\mathrm{P}$ concentration appears to be related to the frequency of corn in the rotation. Potentially mineralizable $\mathrm{N}$ concentration was highest with the S-W rotation, but not different than C-C and S-W-C rotations (Table 2). Potentially mineralizable $\mathrm{N}$ concentration was lowest with the S-S and S-C rotations, which were not different compared to all other rotations except the S-W rotation.

Although the corn crop received starter fertilizer, it is unlikely that the application in the sample year had a large influence on $\mathrm{P}$ concentration or potentially mineralizable $\mathrm{N}$, considering that: (1) sampling was between rows to avoid the band of starter $\mathrm{N}$ fertilizer, (2) soil sampling occurred before split $\mathrm{N}$ application, and (3) each phase of the rotation was sampled, but there were no differences between crop phases (data not shown) on $\mathrm{P}$ concentration or potentially mineralizable $\mathrm{N}$ or any other CSHA parameter. For example, potentially mineralizable $\mathrm{N}$ in S-C and C-S rotations was 7.4 and $7.5 \mathrm{mg}$ $\mathrm{kg}^{-1}$, respectively. Therefore, differences among crop rotations in $\mathrm{P}$ concentration and potentially mineralizable $\mathrm{N}$ in the 0 - to $15-\mathrm{cm}$ depth were likely due to long-term rotational effects rather than a reflection of spring fertilizer application that occurred in April. 
Nevertheless, observed differences in soil $\mathrm{P}$ and $\mathrm{N}$ were attributed to fertilizer practices that differed among crop rotations over the long-term.

Though it is difficult to draw much conclusion from the bluegrass fencerow data because only one site was sampled, CSHA score and all parameters except nutrients were numerically higher in the adjacent undisturbed bluegrass fencerow compared with the trial area (Table 2). Nutrients tended to be lower in the bluegrass fencerow compared with the crop rotations (Table 2), likely due to the lack of fertilizer applied in the fencerow over the long-term. Drury et al. (1998) also observed generally higher aggregate stability and organic, microbial and soluble $\mathrm{C}$ within continuous bluegrass and adjacent woodlot compared with C-C and corn rotated with oats and alfalfa.

\section{Tillage}

In the 0 - to $15-\mathrm{cm}$ soil depth, tillage had no effect on concentrations of $\mathrm{P}, \mathrm{Ca}, \mathrm{Mg}, \mathrm{Mn}$, active carbon, $\mathrm{CEC}$, soil moisture (field capacity, permanent wilting point, and available water capacity), and root health $(P=$ 0.0518 to 0.9341 ; Table 1). The lack of difference between tillage systems at Ridgetown was in contrast to results in Ohio, where CEC, \% SOC, and available water capacity were higher with NT than CT in the 0 - to 15-cm depth (Mahboubi et al. 1993). Chang and Lindwall (1992) reported water content in the 0 - to $30-\mathrm{cm}$ soil depth at $-1500 \mathrm{kPa}$ was higher in NT compared with $\mathrm{CT}$, but there was no difference at $-10 \mathrm{kPa}$. The lack of difference between tillage systems in available water capacity at Ridgetown was similar to other reports (Pikul et al. 1993; Fuentes et al. 2009).

It has been previously reported that $\mathrm{P}$ concentration in the top 15 or $20 \mathrm{~cm}$ was higher in NT compared with CT (Cannell and Hawes 1994; Sisti et al. 2004; Deubel et al. 2011), which tended to be similar to Ridgetown $(P=0.0832$; Table 1$)$. For soil quality indicators with significant tillage effects $(P<0.05)$, compared with $\mathrm{CT}$, the NT production system had a higher soil quality (Table 1). For instance, potentially mineralizable $\mathrm{N}$ was $3.45 \mathrm{mg} \mathrm{kg}^{-1}$ higher $(P=0.0003)$ and $\mathrm{OM}$ was $0.39 \%$ higher $(P=0.0406)$ in the NT compared with the CT system in the 0 - to $15-\mathrm{cm}$ soil depth (Table 1). Although within an optimal range, soil $\mathrm{pH}$ was higher in CT $(\mathrm{pH}=6.85)$ compared with the NT system $(\mathrm{pH}=6.45)$ after $14 \mathrm{yr}$ of production $(P=0.0001$; Table 1$)$. It is important to note that no lime was applied in the Ridgetown long-term trials.

The acidification of surface soil in NT soils has been well documented (Blevins et al. 1983; Cannell and Hawes 1994; Gál et al. 2007). Surface application of N fertilizer in NT system and the lack of soil mixing likely contributed to the lower soil $\mathrm{pH}$ in 0 - to $15-\mathrm{cm}$ compared with CT system, as was observed by Blevins et al. (1983). In contrast to Ridgetown, other long-term tillage studies found no effect on soil $\mathrm{pH}$ in the 0 - to 20-cm or 0- to 60cm depths (Fuentes et al. 2009; Deubel et al. 2011).

Aggregate stability was lower in CT compared with NT $(P<0.0001)$, with 28.0 and $46.1 \%$ water-stable aggregates in CT and NT systems, respectively (Table 1), which was consistent with previous reports (Raimbault and Vyn 1991; Mahboubi et al. 1993; Vyn and Raimbault 1993; Cannell and Hawes 1994). Similar to Ridgetown, an 8-yr study on a prairie loam soil showed slight differences in stable aggregates and other soil physical properties between tillage practices; however, there were no differences observed between tillage systems on crop yield (Chang and Lindwall 1992). Higher water-stable aggregates in the NT system compared with CT may influence surface crusting and susceptibility to erosion.

Cone penetrometer resistance in 0 - to $15-\mathrm{cm}$ depth was higher in NT than CT at Ridgetown $(P<0.0001$; Table 1), which was consistent with many other studies (Vyn and Paimbault 1993; Deubel et al. 2011; Shi et al. 2011, 2012; Munkholm et al. 2013). Higher resistance with NT compared with CT was expected because of the lack of tillage disturbance, which lifts and aerates soil. Considering that penetrometer resistance in NT was $2.05 \mathrm{MPa}$ and values $>2.0 \mathrm{MPa}$ have been considered the threshold for impeding root growth (Reynolds et al. 2002), it is possible that root growth was impeded but perhaps not to a great extent. At Elora, Vyn and Raimbault (1993) observed NT C-C had higher penetrometer readings, bulk density and lower proportion of fine aggregates in the seedbed compared with CT C-C system. These differences partially explained observed lower corn yield in a 15-yr Ontario C-C monoculture system in Elora (Vyn and Raimbault 1993) and were likely drivers influencing crop yield at Ridgetown based on CSHA results (Table 1).

Soil moisture parameters were not different between NT and CT $(P=0.0518$ to 0.9027 ; Table 1$)$, which supports the conclusions in a review by Cannell and Hawes (1994). Similar to Ridgetown, in an Iowa study gravimetric moisture content at field capacity $(-10$ $\mathrm{kPa}$ ) was not different between tillage systems (Benjamin 1993). However, Benjamin (1993) indicated higher hydraulic conductivity with NT compared with CT likely due to either a greater continuity of pores, or greater water flow through large pores. Pore size and distribution were not measured at Ridgetown.

Overall, the composite CSHA soil quality score was $4.4 \%$ higher in NT compared with the CT production system $(P=0.0035$; Table 1$)$. Thus, the CSHA detected statistically significant improvements in soil quality with $14 \mathrm{yr}$ of NT on a Brookston clay loam soil. Improved soil quality with NT compared with CT was consistent with other research (Idowu et al. 2009). For instance, in two S-C sites in New York, soil quality measured by the CSHA was $12-13 \%$ higher in NT compared with CT after 15 -yr long-term studies on clay loam and silt loam soils (Idowu et al. 2009). 
Despite the $4.4 \%$ difference in overall soil health between NT and CT, both systems were ranked as having medium soil quality. Similarly, the S-W rotation was 6.8 to $8.1 \%$ statistically higher than S-S and C-C monocultures and the S-C rotation. The S-W rotation, however, was ranked as high in soil quality as opposed to medium for the other rotations. One might argue that despite the statistical significance observed, the significance of a 4.4 to $8.1 \%$ difference in CSHA scores between tillage systems and among crop rotations seems rather small and the implications difficult to assess.

The CSHA score is a simple unweighted mean of individual soil parameter scores, which may be disproportionately influenced by extreme values. Although not the case at Ridgetown, the approach of unweighted means may not be sufficient to accurately reflect soil health because one parameter can cause crop failure (e.g., poor soil aeration, excessively high/low $\mathrm{pH}$ ) but not be appropriately accounted for in a unweighted mean calculation. Regardless, the CSHA was able to detect differences in soil quality between tillage systems and crop rotations after $14 \mathrm{yr}$, which suggests sensitivity. There is, however, a need to further examine the implications of CSHA scores and evaluate other soil health indices under development nationally and internationally.

Despite differences in the sampling depth of $0-15 \mathrm{~cm}$ for CSHA vs. $0-120 \mathrm{~cm}$ for SOC and total N (see subsequent sections), the interpretation of the impact of tillage system and crop rotation on soil quality was similar among methods. This similarly among soil quality parameters suggests that CSHA may be useful in Ontario. The shallow sample depth used in the CSHA, and the majority of parameters commonly assessed at certified laboratories in North America, as well as the ease of interpretation of results, would make the CSHA appealing to growers and crop consultants. Thus, the CSHA may be useful to growers and crop consultants to assess soil health, particularly when comparing between fields with different management practices.

\section{Soil Organic $\mathrm{C}$ and Total $\mathrm{N}$ on an Equivalent Mass Basis}

\section{Crop Rotation}

The tillage effect for SOC on an equivalent mass basis was not consistent across crop rotations. The tillage by rotation interaction $(P<0.0001)$ for SOC suggests that different rates or processes of $\mathrm{C}$ mineralization and sequestration may exist among tillage and rotation combinations. In order to evaluate the effect of tillage within the different crop rotations, the tillage by crop rotation interaction for each soil depth was sliced across tillage using PROC MIXED (Littell et al. 2006). For the tillage by rotation interaction only, data were presented at three soil depths: the 0 - to $5-\mathrm{cm}$ soil depth representing the disturbed-zone in both tillage systems, the 0 - to $20-\mathrm{cm}$ depth representing the tilled-zone in the CT system, and the 0 - to $100-\mathrm{cm}$ depth, which was the total sample depth.

There were no differences in SOC across crop rotations under NT at 0 - to $5-\mathrm{cm}, 0-$ to $20-\mathrm{cm}$, and 0 - to $100-$ $\mathrm{cm}$ soil depths; however, crop rotation affected SOC under $\mathrm{CT}$ at the 0 - to $5-\mathrm{cm}(P=0.01)$ and the 0 - to $20-\mathrm{cm}$ $(P=0.08)$ soil depths (Table 3). Monoculture of either corn or soybean (i.e., C-C and S-S) under CT tended to produce the lowest SOC compared with other crop rotations, with an average of 12.8 and $48.1 \mathrm{Mg} \mathrm{ha}^{-1}$ SOC at the 0 - to $5-\mathrm{cm}$ and $0-$ to $20-\mathrm{cm}$ soil depths, respectively. The S-S monoculture under $\mathrm{CT}$ tended to produce the lowest SOC in the surface $5 \mathrm{~cm}$ (Table 3),

Table 3. Impact of tillage system ${ }^{\mathrm{z}}$ and crop rotation on soil organic carbon storage after $11 \mathrm{yr}$ in a long-term experiment initiated in 1995

\begin{tabular}{|c|c|c|c|c|c|c|c|c|c|c|c|c|}
\hline \multirow[b]{3}{*}{ Crop rotation } & \multicolumn{12}{|c|}{ Equivalent soil mass $\left(\mathrm{Mg} \mathrm{ha}^{-1}\right)$ with corresponding soil depth $(\mathrm{cm})$} \\
\hline & \multicolumn{4}{|c|}{$731(0-5)$} & \multicolumn{4}{|c|}{$2795(0-20)$} & \multicolumn{4}{|c|}{$14030(0-100)$} \\
\hline & CT & Contrast $^{\mathbf{y}}$ & NT & Across tillage & $\mathrm{CT}$ & Contrast & NT & Across tillage & CT & Contrast & NT & Across tillage \\
\hline & \multicolumn{12}{|c|}{ Organic carbon content $\left(\mathrm{Mg} \mathrm{C}_{\mathrm{ha}}^{-1}\right)$} \\
\hline Continuous corn & $13.7 b c$ & $*$ & 21.2 & $17.0 a b$ & 51.1 & + & 70.9 & 60.2 & 158 & + & 203 & 179 \\
\hline Soybean-corn & $16.7 b$ & NS & 17.5 & $17.1 a b$ & 60.7 & NS & 52.5 & 56.4 & 169 & NS & 162 & 166 \\
\hline Continuous soybean & $11.9 c$ & $*$ & 17.9 & $14.6 b$ & 45.2 & NS & 62.3 & 53.1 & 153 & NS & 181 & 166 \\
\hline Soybean- winter wheat & $21.5 a$ & NS & 25.6 & $23.5 a$ & 79.0 & NS & 79.8 & 79.4 & 190 & NS & 202 & 196 \\
\hline Soybean- winter wheat-corn & $14.1 b$ & $* *$ & 22.6 & $17.8 a b$ & 51.5 & NS & 69.6 & 59.9 & 156 & + & 191 & 173 \\
\hline Across rotation & 15.2 & $* *$ & 20.7 & 18.0 & 56.4 & + & 66.4 & 61.8 & 164 & $*$ & 187 & 176 \\
\hline Difference $^{\mathbf{x}}$ & $*$ & & NS & $*$ & + & & NS & + & NS & & NS & NS \\
\hline Effects & \multirow{2}{*}{\multicolumn{12}{|c|}{$\begin{array}{c}P \text { value } \\
0.08\end{array}$}} \\
\hline Tillage & & & & & & & & & & & & \\
\hline Rotation & \multicolumn{4}{|c|}{0.01} & \multicolumn{4}{|c|}{0.08} & \multicolumn{4}{|c|}{0.30} \\
\hline Interaction & \multicolumn{4}{|c|}{0.29} & \multicolumn{4}{|c|}{0.31} & \multicolumn{4}{|c|}{0.42} \\
\hline
\end{tabular}

${ }^{\mathrm{z}} \mathrm{CT}$, conventional tillage was fall moldboard plough with spring cultivation; NT, no till system had no soil disturbance except at planting.

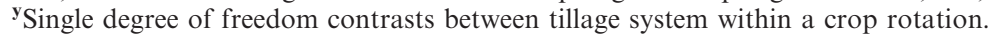

x Statistical differences across rotation, sliced by tillage.

**, *, + , NS Represent statistical significance at $P=0.01, P=0.05, P=0.10$, and $P>0.10$, respectively.

$a-c$ Within each column, means followed by different letters indicate significant difference according to a protected LSD test $(P<0.05)$. 
probably because tillage enhanced decomposition and C mineralization in combination with the low amount of crop residue with soybean compared with corn or winter wheat residues.

In contrast to the monoculture of corn or soybean, the S-W crop rotation produced the highest SOC of 21.5 and $79.0 \mathrm{Mg} \mathrm{ha}^{-1}$ at equivalent depths of $0-5$ and $0-20$ $\mathrm{cm}$, respectively (Table 3 ). The trend for the highest $\mathrm{SOC}$ in the S-W crop rotation may be associated with the frequency of winter wheat in the rotation. High SOC with the S-W rotation under the NT or CT systems may be due to more lignin in wheat residues (i.e., straw), which tends to be more recalcitrant to decomposition.

At Elora, Meyer-Aurich et al. (2006) observed that rotations which included winter wheat (i.e., S-W-C-C) had higher SOC than C-C or S-S-C-C at the $0-$ to $20-\mathrm{cm}$ depth, but no differences at $0-30 \mathrm{~cm}$ or $0-40 \mathrm{~cm}$ on an equivalent mass basis. In contrast, Gál et al. (2007) reported no difference in SOC between $\mathrm{C}-\mathrm{C}$ and $\mathrm{S}-\mathrm{C}$ rotations when averaged for NT and CT systems in a 28-yr study in Indiana, which was similar to results at Ridgetown. Likewise, Yang and Kay (2001a) also reported no difference in SOC between C-C and S-S-C-C rotations at Elora, ON.

Generally, total $\mathrm{N}$ tends with crop rotation mirrored trends in SOC, as reported by others (Franchini et al. 2007; Gál et al. 2007; Fuentes et al. 2009). The tillage system had a much greater influence on $\mathrm{N}$ storage on an equivalent mass basis than crop rotation (Table 4). The tillage system effect on total $\mathrm{N}$ was not consistent with crop rotation, so the tillage by crop rotation interaction for each soil depth was sliced across tillage, which produced single degree of freedom contrasts (Littell et al. 2006) between NT and CT within each crop rotation (Table 4). Total $\mathrm{N}$ was numerically higher under NT in all crop rotations, but most responses were not statistically different in the C-C, S-C, and S-W crop rotations $(P=0.09$ to 0.23$)$ at any of the equivalent soil depths tested. The greatest tillage response on soil $\mathrm{N}$ occurred in the S-S and S-W-C rotations: $\mathrm{N}$ content at equivalent soil depths of $0-5$ and $0-20 \mathrm{~cm}$ was more than double with NT in the S-S monoculture compared to $\mathrm{CT}$, and nearly double in S-W-C rotation $(P=0.0001$ to 0.006). At all depths evaluated, the S-S monoculture under CT had the lowest total $\mathrm{N}$ and was not statistically different than CT C-C monoculture (Table 4).

Total $\mathrm{N}$ data expressed on an equivalent mass basis (Table 4) was similar to total $\mathrm{N}$ content and concentration (data not shown); higher total $\mathrm{N}$ with rotations with winter wheat compared with those rotations without winter wheat. Higher concentrations and quantities of soil $\mathrm{N}$ in systems that include winter wheat may be due to high amounts of $\mathrm{N}$ through rhizodeposition by the wheat crop. Most studies have reported that between 5 and $20 \%$ of total $\mathrm{N}$ assimilated by wheat is deposited into the soil as $\mathrm{N}$ derived from root deposits [reviewed by Wichern et al. (2008)]. Janzen (1990) reported that $18-33 \%$ of the total $\mathrm{N}$ yield of wheat plants was deposited in the soil from root exudates, which represents an important contribution to the soil $\mathrm{N}$ fertility status. In a recent 2-yr study in Spain, Munoz-Romero et al. (2013) reported a total of $93 \mathrm{~kg} \mathrm{~N} \mathrm{ha}^{-1} \mathrm{yr}^{-1}$ was deposited from wheat roots, or approximately $40 \%$ of the total $\mathrm{N}$ content assimilated by wheat plants including grain. Although less is known about $\mathrm{N}$ deposits from corn and soybean roots, wheat roots may contribute more $\mathrm{N}$ due to its dense fibrous root system (MunozRomero et al. 2013), which may explain higher $\mathrm{N}$ content and concentrations in crop rotations that included wheat at Ridgetown.

\begin{tabular}{|c|c|c|c|c|c|c|c|c|c|c|c|c|}
\hline \multirow[b]{3}{*}{ Crop rotation } & \multicolumn{12}{|c|}{ Equivalent soil mass $\left(\mathrm{Mg} \mathrm{ha}^{-1}\right)$ with corresponding soil depth $(\mathrm{cm})$} \\
\hline & \multicolumn{4}{|c|}{$731(0-5)$} & \multicolumn{4}{|c|}{$2795(0-20)$} & \multicolumn{4}{|c|}{$14030(0-100)$} \\
\hline & $\mathrm{CT}$ & Contrast $^{\mathbf{y}}$ & NT & Across Tillage & $\mathrm{CT}$ & Contrast & NT & Across Tillage & $\mathrm{CT}$ & Contrast & NT & Across Tillage \\
\hline & \multicolumn{12}{|c|}{ 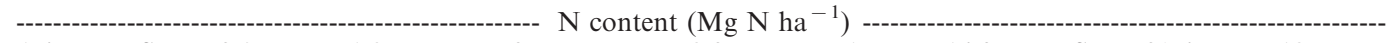 } \\
\hline Continuous corn & 1.4 & NS & 2.3 & 1.8 & 5.2 & + & 8.2 & 7.1 & 14.9 & NS & 20.4 & 18.5 \\
\hline Soybean-corn & 2.0 & NS & 2.7 & 2.4 & 7.4 & NS & 8.8 & 8.7 & 19.1 & NS & 22.7 & 22.1 \\
\hline Continuous soybean & 1.1 & + & 2.5 & 1.8 & 4.2 & + & 9.0 & 7.2 & 12.7 & + & 23.4 & 19.4 \\
\hline Soybean- winter wheat & 2.6 & NS & 3.9 & 3.2 & 10.4 & NS & 15.0 & 13.5 & 22.2 & + & 33.8 & 29.1 \\
\hline Soybean- winter wheat-corn & 1.9 & + & 3.8 & 2.8 & 7.3 & + & 12.8 & 10.4 & 18.4 & $*$ & 30.9 & 25.3 \\
\hline Across rotation & 1.7 & $* *$ & 3.1 & 2.4 & 6.8 & $* *$ & 12.2 & 9.4 & 17.5 & ** & 29.0 & 22.9 \\
\hline Difference $^{\mathrm{x}}$ & NS & & NS & NS & NS & & NS & + & NS & & NS & NS \\
\hline \multicolumn{13}{|l|}{ Effects } \\
\hline Tillage & \multicolumn{4}{|c|}{0.006} & \multicolumn{4}{|c|}{0.003} & \multicolumn{4}{|c|}{0.000} \\
\hline Rotation & \multicolumn{4}{|c|}{0.22} & \multicolumn{4}{|c|}{0.09} & \multicolumn{4}{|c|}{0.23} \\
\hline Interaction & \multicolumn{4}{|c|}{0.91} & \multicolumn{4}{|c|}{0.90} & \multicolumn{4}{|c|}{0.91} \\
\hline
\end{tabular}

${ }^{\mathrm{z}} \mathrm{CT}$, conventional tillage was fall moldboard plough with spring cultivation; NT, no till system had no soil disturbance except at planting.

${ }^{\mathbf{y}}$ Single degree of freedom contrasts between tillage systems within crop rotation.

${ }^{\mathrm{x}}$ Statistical differences across rotation, sliced by tillage.

**, * + , NS Represent statistical significance at $P=0.01, P=0.05, P=0.10$, and $P>0.10$, respectively. 


\section{Tillage Systems}

In the 1991 tillage trial with a S-C rotation, in the equivalent soil mass of 638,2443 , and $10256 \mathrm{Mg} \mathrm{ha}^{-1}$, which corresponded to $0-5,0-20$ and $0-80 \mathrm{~cm}$ depths, SOC was 15 to $18 \%$ higher with NT than CT, respectively, and the NT system had 14 to $27 \%$ higher total N than CT system (Table 5). The chisel-T treatment was either intermediary to NT and CT or more similar to CT than NT with respect to both SOC and total N (Table 5). Similarly, pooled over crop rotation in the 1995 trial, SOC and total $\mathrm{N}$ were also statistically higher with NT than CT (Tables 3 and 4). Thus, in both long-term sites at Ridgetown NT had greater SOC and total N compared to CT.

In contrast to Ridgetown, reports in Ontario from Elora (Deen and Kataki 2003), Delhi (Wanniarachchi et al. 1999), and Woodslee (Yang et al. 2008a) showed no differences in SOC among tillage treatments. Likely, different soil characteristics and experimental duration contributed to the different effect of tillage on SOC at the aforementioned Ontario sites compared with Ridgetown. West and Post (2002) estimated that SOC sequestration rates establish new equilibriums by $15-20 \mathrm{yr}$ when comparing NT and CT practices. Also, Alvarez (2005) concluded that the accumulation of SOC under reduced tillage or NT had an S-shaped time-dependent process and reached a steady state after 25-30 yr. Considering the assessment of SOC at Ridgetown was after 11-15 yr of production, it would be valuable to re-sample after circa $20 \mathrm{yr}$ to determine if SOC and soil quality values were at peak or equilibrium.

Regardless, there has been increased evidence of higher SOC with NT than CT in the deeper soil profile (i.e., below $60-\mathrm{cm}$ depth). For instance, results in
Indiana in $\mathrm{C}-\mathrm{C}$ and $\mathrm{S}-\mathrm{C}$ rotations showed higher $\mathrm{SOC}$ and total $\mathrm{N}$ on an equivalent mass basis in $\mathrm{NT}$ compared with CT to 100-cm depth (Gál et al. 2007). In a S-W-C rotation, NT had higher SOC than CT in a 19-yr, farm-scale trial in southern Ontario (Yang and Kay 2001b). Correspondingly, a global meta-analysis showed NT had $48 \mathrm{~g} \mathrm{C} \mathrm{m}^{-2} \mathrm{yr}^{-1}$ greater C than CT (West and Post 2002). Likewise, a recent meta-analysis of Ontario long-term tillage trials, which included both 1991 and 1995 long-term Ridgetown sites showed at all depths evaluated $(0-10,0-20$, and $0-45 \mathrm{~cm})$ greater SOC storage with NT than CT systems by $6.9 \mathrm{~g} \mathrm{C} \mathrm{m}^{-2} \mathrm{yr}^{-1}$ in the 0- to 45-cm depth (Congreves et al. 2014).

Similar to SOC, in both long-term trials at Ridgetown, total $\mathrm{N}$ was higher with NT than CT at each depth to at least $60 \mathrm{~cm}$ (Table 5). Soil total $\mathrm{N}$ at both sites in Ridgetown was consistent with others that showed NT system to have a greater impact on soil $\mathrm{N}$ than previous crops (Soon et al. 2001). No-till soils tend to have higher levels of microbial biomass and organic $\mathrm{N}$ compared with CT soils (Doran 1987; Soon et al. 2001). Higher total soil N content and concentration with NT compared with CT system was similar with potentially mineralizable $\mathrm{N}$ in the 0 - to $15-\mathrm{cm}$ depth (Table 1 ).

In both trials, there was no tillage by depth interaction ( $P=0.7233$ to 0.9999$)$ when the data were expressed by concentration, content (data not shown) or on an equivalent mass basis for SOC and total N, which suggests differential stratification of SOC and total $\mathrm{N}$ between tillage systems did not occur. The lack of stratification of SOC under long-term NT compared with CT systems was not in agreement with other research [see review by Kay and VandenBygaart (2002)], which observed NT systems

Table 5. Impact of tillage ${ }^{\mathrm{z}}$ and sample depth on soil organic carbon (SOC) and nitrogen storage on equivalent soil mass basis in two long-term trials initiated in 1991 and 1995

\begin{tabular}{|c|c|c|c|c|c|c|c|c|c|c|c|c|}
\hline \multirow{3}{*}{$\begin{array}{l}\text { Soil } \\
\text { depth } \\
\text { (cm) }\end{array}$} & \multicolumn{7}{|c|}{1991 tillage trial } & \multicolumn{5}{|c|}{1995 tillage-rotation trial } \\
\hline & \multirow{2}{*}{$\begin{array}{l}\text { Equivalent soil } \\
\text { mass }\left(\mathrm{Mg} \mathrm{ha}^{-1}\right)\end{array}$} & \multicolumn{3}{|c|}{$\operatorname{SOC}\left(\mathrm{Mg} \mathrm{C} \mathrm{ha}^{-1}\right)$} & \multicolumn{3}{|c|}{$\mathrm{N}\left(\mathrm{Mg} \mathrm{N} \mathrm{ha}^{-1}\right)$} & \multirow{2}{*}{$\begin{array}{l}\text { Equivalent soil } \\
\text { mass }\left(\mathrm{Mg} \mathrm{ha}^{-1}\right)\end{array}$} & \multicolumn{2}{|c|}{$\operatorname{SOC}\left(\mathrm{Mg} \mathrm{C} \mathrm{ha}^{-1}\right)$} & \multicolumn{2}{|c|}{$\mathrm{N}\left(\mathrm{Mg} \mathrm{N} \mathrm{ha}^{-1}\right)$} \\
\hline & & $\mathrm{CT}$ & NT & Chisel & $\mathrm{CT}$ & NT & Chisel & & $\mathrm{CT}$ & NT & $\mathrm{CT}$ & NT \\
\hline $0-5$ & 638.4 & $13.2 c$ & $16.8 a$ & $15.5 b$ & $1.35 b$ & $1.63 a$ & $1.44 a b$ & 731 & $15.5 b$ & $21.1 a$ & $1.77 b$ & $3.30 a$ \\
\hline $0-10$ & 1226 & $25.7 b$ & $30.5 a$ & $28.8 a b$ & $2.61 b$ & $3.05 a$ & $2.77 a b$ & 1367 & $28.7 b$ & $36.3 a$ & $3.36 b$ & $5.85 a$ \\
\hline $0-15$ & 1827 & $37.8 b$ & $44.2 a$ & $41.0 a b$ & $3.89 b$ & $4.46 a$ & $4.05 a b$ & 2167 & $45.4 b$ & $54.9 a$ & $5.36 b$ & $9.00 a$ \\
\hline $0-20$ & 2443 & $48.7 b$ & $57.6 a$ & $51.5 a b$ & $5.04 b$ & $5.81 a$ & $5.10 a b$ & 2795 & $57.3 b$ & $68.4 a$ & $6.79 b$ & $12.3 a$ \\
\hline $0-30$ & 3680 & $63.9 b$ & $78.5 a$ & $67.8 b$ & $6.68 b$ & $7.85 a$ & $6.67 b$ & 4235 & $76.0 b$ & $89.4 a$ & $9.17 b$ & $16.1 a$ \\
\hline $0-40$ & 5023 & $75.4 b$ & $92.5 a$ & $80.7 b$ & $7.81 b$ & $9.12 a$ & $7.72 b$ & 5600 & $86.8 b$ & $103 a$ & $10.5 b$ & $18.4 a$ \\
\hline $0-50$ & 6318 & $86.3 b$ & $104 a$ & $93.1 a b$ & $8.76 b$ & $10.1 a$ & $8.92 b$ & 6966 & $97.9 b$ & $116 a$ & $11.7 b$ & $20.4 a$ \\
\hline $0-60$ & 7593 & $97.5 b$ & $116 a$ & $106 a b$ & $9.67 b$ & $11.0 a$ & $9.70 b$ & 8330 & $111 b$ & $131 a$ & $12.8 b$ & $22.5 a$ \\
\hline $0-80$ & 10256 & $122 b$ & $141 a$ & $132 a b$ & $11.5 a$ & $12.7 a$ & $11.6 a$ & 11190 & $137 b$ & $160 a$ & $15.2 b$ & $26.6 a$ \\
\hline $0-100$ & 13053 & $147 a$ & $168 a$ & $160 a$ & $13.3 a$ & $14.3 a$ & $13.3 a$ & 14030 & $164 b$ & $190 a$ & $17.5 b$ & $30.2 a$ \\
\hline \multirow{3}{*}{$\begin{array}{l}\text { Effects } \\
\text { Tillage } \\
\text { Mass } \\
\text { Interaction }\end{array}$} & & $<0.0001$ & & & $<0.0001$ & $P$ & le & & $<0.0001$ & & $<0.0001$ & \\
\hline & & $<0.0001$ & & & $<0.0001$ & & & & $<0.0001$ & & $<0.0001$ & \\
\hline & & 0.9996 & & & 0.9997 & & & & 0.7233 & & 0.9999 & \\
\hline
\end{tabular}

${ }^{\mathrm{z}} \mathrm{CT}$, conventional tillage was fall moldboard plough with spring cultivation; Chisel was fall chisel plough with spring cultivation; NT, no till system had no soil disturbance except at planting.

$a-c$ For each trial within each row and each parameter, means followed by different letters indicate significant difference according to Tukey-Kramer multiple means comparison $(P<0.05)$. 
had a stratified SOC distribution within the soil profile but did not increase SOC storage beyond the plough layer (Deen and Kataki 2003; Murage et al. 2007; Angers et al. 2008; Yang et al. 2008b; Shi et al. 2011).

Differences in sample depths may somewhat explain discrepancies between studies on the impact of tillage systems on SOC (Yang and Kay 2001b). Meta-analysis by VandenBygaart et al. (2003) suggested no difference in SOC between tillage systems in eastern Canada but interpretation of results may be limited by the relatively shallow sampling depths (generally $30 \mathrm{~cm}$ or less). Yang et al. (2008b) suggested that it may not be appropriate to sample to $100 \mathrm{~cm}$ because tillage practices might not have been in production long enough to affect deeper depths. Moreover, variability in SOC storage increases with depths, which limits the possibility of observing treatment effects. Although the aforementioned is undoubtedly true, one should not dismiss sampling at deeper depths (i.e., $>60 \mathrm{~cm}$ ) in order to avoid underestimating $\mathrm{C}$ and $\mathrm{N}$ storage in long-term tillage and crop rotation studies (Gál et al. 2007; VandenBygaart et al. 2011). Thus, in both trials at Ridgetown that were sampled to $120 \mathrm{~cm}$ depth, there was no tillage by depth interaction for SOC and total $\mathrm{N}$ on an equivalent mass basis, and tillage effects were consistent among the soil depth increments with higher SOC and total N in NT vs. CT.

As with the majority of long-term research, our study did not quantify $\mathrm{C}$ and $\mathrm{N}$ in crop residues on the soil surface or in the soil. The higher quantity of crop residues on the soil surface between crop species and in NT compared with CT has been well documented but rarely included into estimates of soil $\mathrm{C}$ contents. Based on visual observations one would speculate that including crop residues into estimates of SOC and total $\mathrm{N}$ would not change the interpretation of results for tillage systems (i.e., higher SOC and total N with NT compared with CT) and likely lower SOC and total $\mathrm{N}$ in S-S compared with other rotations. Future research should include surface and sub-surface crop residues in estimates of SOC and total N, especially within long-term tillage and crop rotation experiments.

Other factors such as dissolved organic $\mathrm{C}$ transport, root distribution, SOC mineralization and earthworm populations may have contributed to the observed higher SOC in NT than CT at Ridgetown. Similar to other research (Kladivko et al. 1997; VandenBygaart et al. 1998; Reeleder et al. 2006), in the tillage trial at Ridgetown the counts for earthworm middens in NT was 74.4 middens $\mathrm{m}^{-2}$, which was 48.3 and $61.6 \%$ higher than in chisel-T and CT systems, respectively $(P<0.0001)$. There were no difference in earthworm middens between chisel-T and CT systems, which had 26.1 and 12.8 middens $\mathrm{m}^{-2}$, respectively. Undoubtedly, earthworms contributed to the distribution of SOC within the soil profile; however, it does not appear that observed higher Lumbricus terrestris populations in NT than CT significantly limited SOC storage in NT at Ridgetown. Higher L. terrestris populations in NT than CT may have diminished the stratifica- tion of SOC in NT systems at Ridgetown. The observed higher earthworm middens in NT than CT and chisel-T many have increased transport of dissolved organic $\mathrm{C}$ to subsurface soil with percolation and preferential flow, thereby contributing to SOC distribution and storage. Gál et al. (2007) suggested that higher SOC in NT than $\mathrm{CT}$ below the plough layer may be due to higher root density and distribution as well as root exudation in the NT than CT systems. The greater SOC content with NT than CT at Ridgetown may be a reflection of a reduced rate of SOC mineralization rather than SOC sequestration, as previously hypothesized by Kay and VandenBygaart (2002). Moreover, Kay and VandenBygaart (2002) suggested that there may be a difference in the rate of SOC gains near surface and losses at depth. Higher SOC with NT at both Ridgetown sites was consistent with observed lower decomposition rate of crop residues and more stable $\mathrm{C}$ components with minimum tillage than $\mathrm{CT}$ by Beyaert and Voroney (2011). Further research into differences between tillage systems and crop rotations in the soil profile on $\mathrm{C}$ and $\mathrm{N}$ dynamics with regards to soil moisture, temperature, and biological activity, including earthworms are needed.

Most agricultural SOC research has focused on the top $30 \mathrm{~cm}$ soil, yet our study demonstrated deep soil layers (beyond the plough layer) contained as much or more SOC $\left(\mathrm{Mg} \mathrm{ha}^{-1}\right)$ than the surface layers. Input of SOC to subsurface soil can be from dissolved organic C, root biomass and physically or biologically transported particulate organic matter; however, little is known of the relative importance of deep soil $\mathrm{C}$ input, stabilization and destabilization (Rumpel and Kögel-Knabner 2011). It is hypothesized that the input or transport of dissolved organic $\mathrm{C}$ or SOC to subsurface soil was greater in NT vs. CT at Ridgetown. Tillage likely disrupted the physical structure and nutrient supply to subsurface soil microorganisms, which was previously identified as a major factor in destabilizing deep SOC (Rumpel and Kögel-Knabner 2011). Although dissolved organic C was not measured in the current study, a 20-yr trial demonstrated that dissolved organic $\mathrm{C}$ distribution by depth was similar to SOC and to $\mathrm{N}$ and the proportion of SOC as dissolved organic $\mathrm{C}$ increased with soil depth up to $105 \mathrm{~cm}$ (Wright et al. 2007). Future research should evaluate how tillage and rotational regimes can impact the input or transport of SOC to subsurface soil.

\section{CONCLUSIONS}

Maintaining and building soil quality is essential for competitive, sustainable agricultural production, and long-term research experiments are invaluable for assessing the impacts of management practices on soil quality. This is the first published report on soil quality in the long-term experiments at Ridgetown; differences among crop rotations and tillage systems on SOC and soil quality after 11 to $15 \mathrm{yr}$. Interpretation of the impact of tillage system and crop rotation on soil quality was similar using the CSHA at $0-$ to $15-\mathrm{cm}$ depth and SOC 
and total $\mathrm{N}$ on an area basis or on an equivalent soil mass basis to 0 - to $100-\mathrm{cm}$ depth. This result suggests that CSHA may be useful in Ontario.

Similar to CHSA, SOC and total $\mathrm{N}$ data suggest soil quality was higher in NT than CT and higher with winter wheat in the rotation. Tillage had a larger influence on $\mathrm{C}$ and $\mathrm{N}$ storage than crop rotation. Although in contrast to previous research in eastern Canada, in both longterm trials at Ridgetown, NT had ca. $21 \mathrm{Mg} \mathrm{ha}^{-1}$ more or $14 \%$ higher SOC than CT but chisel-T was not statistically different than NT or CT. Overall our results suggest that to improve soil quality and SOC and total N content, growers on clay loam soil in southwestern Ontario should consider incorporating winter wheat into the rotation and adopting NT production practices.

Total $\mathrm{N}$ and SOC content estimates were calculated on an equivalent mass basis to $100 \mathrm{~cm}$ depth but similar trends were observed at shallower depths too. Sampling well below the tillage depth provides a more accurate assessment of $\mathrm{C}$ and $\mathrm{N}$ storage and the impact of management practises on these chemical parameters. A common limitation in long-term tillage and rotation research on soil properties is not including estimates of crop residues on the soil surface and in subsurface soil into estimates of SOC and total N. Although we speculate that the findings would not be different from those presented herein if crop residues were included, one would expect a more accurate assessment of $\mathrm{C}$ and $\mathrm{N}$ storage.

\section{ACKNOWLEDGEMENTS}

The authors gratefully thank D. Young and S. Jay for establishing and maintaining the long-term trials at Ridgetown, Dr. W. D. Reynolds for determining available water capacity, and Dr. R. P. Beyaert for conducting SOC and total $\mathrm{N}$ sample analyses.

Abawi, G. S., Ludwig, J. W. and Petzoldt, C. H. 2004. Assessing root health by a soil bioassay with beans as an indicator of soil health. Phytopathology 94: S1: (Abstract No. 579B).

Alvarez, R. 2005. A review of nitrogen fertilizer and conservation tillage effects on soil organic carbon storage. Soil Use Manage. 21: 38-52.

Andrews, S. S., Karlen, D. L. and Cambardella, C. A. 2004. The soil management assessment framework: A quantitative soil quality evaluation method. Soil Sci. Soc. Am. J. 68: 1945-1962. Angers, D. A. and Eriksen-Hamel, N. S. 2008. Full-inversion tillage and organic carbon distribution in soil profiles: A metaanalysis. Soil Sci. Soc. Am. J. 72: 1370-1374.

Angers, D., Bolinder, M., Carter, M., Gregorich, E., Drury, C., Liang, B., Voroney, R. P., Simard, R., Donald, R. and Beyaert, R. 1997. Impact of tillage practices on organic carbon and nitrogen storage in cool, humid soils of eastern Canada. Soil Tillage Res. 41: 191-201.

Arias, M., Gonzalez-Perez, J., Gonzalez-Vila, F. and Ball, A. 2005. Soil health, a new challenge for microbiologists and chemists. Int. Microbiol. 8: 13-21.
Aziz, I., Mahmood, T. and Islam, K. R. 2013. Effect of long term no-till and conventional tillage practices on soil quality. Soil Tillage Res. 131: 28-35.

Benjamin, J. G. 1993. Tillage effects on near-surface soil hydraulic properties. Soil Tillage Res. 26: 277-288.

Blevins, R. L., Thomas, G. W., Smith, M. S., Frye, W. W. and Cornelius, P. L. 1983. Changes in soil properties after 10 years continuous non-tilled and conventionally tilled corn. Soil Tillage Res. 3: 135-146.

Beyaert, R. P. and Voroney, R. P. 2011. Estimation of decay constants for crop residues measured over 15 years in conventional and reduced tillage systems in a coarse-textured soil in southern Ontario. Can. J. Soil Sci. 91: 985-995.

Bolinder, M. A., Angers, D. A., Gregorich, E. G. and Carter, M. R. 1999. The response of soil quality indicators to conservation management. Can. J. Soil Sci. 79: 37-45.

Cannell, R. Q. and Hawes, J. D. 1994. Trends in tillage practices in relation to sustainable crop production with special reference to temperature climates. Soil Tillage Res. 30: $245-282$.

Carter, M. R. 2005. Long-term effects on cool-season soybean in rotation with barley, soil proerties, and carbon and nitrogen storage for fine sandy loams in the humid climate of Atlantic Canada. Soil Tillage Res. 81: 109-120.

Chang, C. and Lindwall, C. W. 1992. Effects of tillage and crop rotation on physical properties of a loam soil. Soil Tillage Res. 22: 383-389.

Congreves, K. A., Smith, J. M., Németh, D. D., Hooker, D. C. and Van Eerd, L. L. 2014. Soil organic carbon and land use: processes and potential in Ontario's long-term agro-ecosystem research sites. Can. J. Soil. Sci. 94: 317-336.

Deen, W. and Kataki, P. 2003. Carbon sequestration in a longterm conventional versus conservation tillage experiment. Soil Tillage Res. 74: 143-150.

Deubel, A., Hofmann, B. and Orzessek, D. 2011. Long-term effects of tillage on stratification and plant availability of phosphate and potassium in a loess chernozem. Soil Tillage Res. 117: 85-92.

Doran, J. W. 1987. Microbial biomass and mineralizable nitrogen distributions in no-tillage and plowed soils. Biol. Fertil. Soils. 5: 68-75.

Doran, J. W. and Parkin, T. B. 1994. Defining and assessing soil quality. Pages 3-21 in J. W. Doran, D. C. Coleman, D. F. Bezdicek, and B. A. Stewart, eds. Defining soil quality for a sustainable environment. Special Publication No. 35. SSSA, ASA, Madison, WI.

Drinkwater, L. E., Cambardella, C. A., Reeder, J. D. and Rice, C. W. 1996. Potentially mineralizable nitrogen as an indicator of biologically active soil nitrogen. Pages 217-229 in J. W. Doran and A. J. Jones, eds. Methods for assessing soil quality. Special Edition No. 49. SSSA, Madison, WI.

Drury, C. F., Oloya, T. O., McKenney, D. J., Gregorich, E. G., Tan, C. S. and vanLuyk, C. L. 1998. Long-term effects of fertilization and rotation on denitrification and soil carbon. Soil Sci. Soc. Am. J. 62: 1572-1579.

Ellert, B. H. and Bettany, J. R. 1995. Calculation of organic matter and nutrients stored in soils under contrasting management regimes. Can. J. Soil Sci. 75: 529-538.

Franchini, J. C., Crispino, C. C., Souza, R. A., Torres, E. and Hungria, M. 2007. Microbiological parameters as indicators of soil quality under various soil management and crop rotation systems in southern Brazil. Soil Tillage Res. 92: 18-29. 
Fuentes, M., Govaerts, B., De León, F., Hidalgo, C., Dendooven, L., Sayre, K. D. and Etchevers, J. 2009. Fourteen years of applying zero and conventional tillage, crop rotation and residue management systems and its effect on physical and chemical soil quality. Eur. J. Agron. 30: 228-237.

Gál, A., Vyn, T. J., Michéli, E., Kladivko, E. J. and McFee, W. W. 2007. Soil carbon and nitrogen accumulation with longterm no-till versus moldboard plowing overestimated with tilled-zone sampling depths. Soil Tillage Res. 96: 42-51.

Gugino, B. K., Idowu, O. J., Schindelbeck, R. R., van Es, H. M., Wolfe, D. W., Moebius, B. N., Thies, J. E. and Abawi, G. S. 2007. Cornell soil health assessment training manual. Edition 1.2. Cornell University, Geneva, NY.

Idowu, O. J., van Es, H. M., Abawi, G. S., Wolfe, D. W., Ball, J. I., Gugino, B. K., Moebius, B. N., Schindelbeck, R. R. and Bilgili, A. V. 2008. Farmer-oriented assessment of soil quality using field, laboratory, and VNIR spectroscopy methods. Plant Soil 307: 243-253.

Idowu, O. J., Van Es, H. M., Abawi, G. S., Wolfe, D. W., Schindelbeck, R. R., Moebius-Clune, B. N. and Gugino, B. K. 2009. Use of an integrative soil health test for evaluation of soil management impacts. Renew. Agric. Food Syst. 24: 214-224. Janzen, H. H. 1990. Deposition of nitrogen into the rhizosphere by wheat roots. Soil Biol. Biochem. 22: 1155-1160.

Karlen, D. L., Ditzler, C. A. and Andrews, S. S. 2003. Soil quality: why and how? Geoderma 114: 145-156.

Karlen, D. L., Andrews, S. S., Wienhold, B. J. and Zobeck, T. M. 2008. Soil quality assessment: Past, present and future. J. Integr. Biosci. 6: 3-14.

Karlen, D. L., Cambardella, C. A., Kovar, J. L. and Colvin, T. S. 2013. Soil quality response to long-term tillage and crop rotation practices. Soil Tillage Res. 133: 54-64.

Kay, B. D. and VandenBygaart, A. J. 2002. Conservation tillage and depth stratification of porosity and soil organic matter. Soil Tillage Res. 66: 107-118.

Kennedy, A. and Smith, K. 1995. Soil microbial diversity and the sustainability of agricultural soils. Plant Soil. 170: 75-86.

Kladivko, E. J., Akhouri, N. M. and Weesies, G. 1997. Earthworm populations and species distribution under no-till and conventional tillage in Indiana and Illinois. Soil Biol. Biochem. 29: 613-615.

Littell, R. C., Milliken, G. A., Stroup, W. W., Wolfinger, R. D. and Schabenberger, O. 2006. SAS(r) for mixed models. 2nd ed. SAS Institute, Inc., Cary, NC. pp. 124-127.

Mahboubi, A. A., Lal, R. and Fausey, N. R. 1993. Twenty-eight years of tillage effects on two soils in Ohio. Soil Sci. Soc. Am. J. 57: 506-512.

McGonigle, T. P., Miller, M. M. and Young, D. 1999. Mycorrhizae, crop growth, and crop phosphorus nutrition in maize-soybean rotations given various tillage treatments. Plant Soil 210: 33-42.

Meyer-Aurich, A., Weersink, A., Janovicek, K. and Deen, W. 2006. Cost efficient rotation and tillage options to sequester carbon and mitigate GHG emissions from agriculture in Eastern Canada. Agric. Ecosyst. Environ. 117: 119-127.

Munoz-Romero, V., Lopez-Bellido, R. J., Relondo, R and Lopez-Bellido, L. 2013. Nitrogen rhizodeposition by wheat under different tillage systems in a rainfed Vertisol. Field Crops Res. 144: 148-153.

Murage, E. W., Voroney, R. P., Kay, B. D., Deen, B. and Beyaert, R. P. 2007. Dynamics and turnover of soil organic matter and its density fractions as affected by tillage. Soil Sci. Soc. Am. J. 71: 1363-1370.

Munkholm, L. J., Heck, R. J. and Deen, B. 2013. Long-term rotation and tillage effects on soil structure and crop yield. Soil Tillage Res. 127: 85-91.

Ogden, C. B., Van Es, H. M. and Schindelbeck, R. R. 1997. Miniature rain simulator for field measurement of soil infiltration. Soil Sci. Soc. Am. J. 61: 1041-1043.

Ontario. 2009. Agronomy guide for field crops. Publication 811. Ministry of Agriculture, Food and Rural Affairs. Queen's Printer for Ontario. Toronto, ON. pp. 320.

Pikul, Jr., J. L., Ramig, R. E. and Wilkins, D. E. 1993. Soil properties and crop yield among four tillage systems in a wheat-pea rotation. Soil Tillage Res. 26: 151-162.

Raimbault, B. A. and Vyn, T. J. 1991. Crop rotation and tillage effects on corn growth and soil structural stability. Agron. J. 83: 979-985.

Reeleder, R., Miller, J., Ball-Coelho, B. and Roy, R. 2006. Impacts of tillage, cover crop, and nitrogen on populations of earthworms, microarthropods, and soil fungi in a cultivated fragile soil. App. Soil Ecol. 33: 243-257.

Reynolds, W. D., Bowman, B. T., Drury, C. F., Tan, C. S. and Lu, X. 2002. Indicators of good soil physical quality: density and storage parameters. Geoderma 110: 131-146.

Rumpel, C. and Kögel-Knabner, I. 2011. Deep soil organic matter - a key but poorly understood component of terrestrial C cycle. Plant Soil. 338: 143-158.

Rutherford, P. M., McGill, W. B., Arocena, J. M. and Figueiredo, C. T. 2008. Total nitrogen. Pages 239-250 in M. R. Carter and E. G. Gregorich, eds. Soil sampling and methods of analysis. 2nd ed. CRC Press Inc., Boca Raton, FL. Shi, X., Yang, X., Drury, C. F., Reynolds, W. D., McLaughlin, N. B., Welacky, T. W. and Zhang, X. 2011. Zone tillage impacts on organic carbon of a clay loam in southwestern Ontario. Soil Sci. Soc. Am. J. 75: 1083-1089.

Shi, X. H., Yang, X. M., Drury, C. F., Reynolds, W. D., McLaughlin, N. B. and Zhang, X. P. 2012. Impact of ridge tillage on soil organic carbon and selected physical properties of a clay loam in southwestern Ontario. Soil Tillage Res. 120: $1-7$.

Sisti, C. P. J., Henrique, P., dos Santos, H. P., Kohhann, R., Alves, B. J. R., Urquiaga, S. and Boddey, R. M. 2004. Change in carbon and nitrogen stocks in soil under 13 years of conventional or zero tillage in southern Brazil. Soil Tillage Res. 76: 39-58.

Skjemstad, J. O. and Baldock, J. A. 2008. Total and Organic Carbon. Pages 225-237 in M. R. Carter and E. G. Gregorich, eds. Soil sampling and methods of analysis. 2nd ed. CRC Press Inc., Boca Raton, FL.

Soon, Y. K., Clayton, G. W. and Rice, W. A. 2001. Tillage and previous crop effects on dynamics of nitrogen in a wheat-soil system. Agron. J. 93: 842-849.

Stavi, I., Lal, R., Jones, S. and Reeder, R. C. 2012. Implications of cover crops for soil quality and geodiversity in a humidtemperate region in the Midwestern USA. Land Degrad. Develop. 23: 322-330.

VandenBygaart, A. J., Protz, R., Tomlin, A. D. and Miller, J. J. 1998. ${ }^{137} \mathrm{Cs}$ as an indicator of earthworm activity in soils. Appl. Soil Ecol. 9: 167-173.

VandenBygaart, A., Gregorich, E. and Angers, D. 2003. Influence of agricultural management on soil organic carbon: 
A compendium and assessment of Canadian studies. Can. J. Soil Sci. 83: 363-380.

VandenBygaart, A., Bremer, E., McConkey, B., Ellert, B., Janzen, H., Angers, D., Carter, M., Drury, C., Lafond, G. and McKenzie, R. 2011. Impact of sampling depth on differences in soil carbon stocks in long-term agroecosystem experiments. Soil Sci. Soc. Am. J. 75: 226-234.

Vyn, T. J. and Raimbault, B. A. 1993. Long-term effect of five tillage systems on corn response and soil structure. Agron. J. 85: 1074-1079.

Wanniarachchi, S., Voroney, R. P., Vyn, T. J., Beyaert, R. P. and MacKenzie, A. 1999. Tillage effects on the dynamics of total and corn-residue-derived soil organic matter in two southern Ontario soils. Can. J. Soil Sci. 79: 473-480.

West, T. O. and Post, W. M. 2002. Soil organic carbon sequestration rates by tillage and crop rotation: A global data analysis. Soil Sci. Soc. Am. J. 66: 1930-1946.

Wichern, F., Eberhardt, E., Mayer, J., Joergensen, R. G. and Muller, T. 2008. Nitrogen rhizodeposition in agricultural crops: methods, estimates, and future prospects. Soil Biol. Biochem. 40: 30-48.
Wright, A. L., Dou, F. and Hons, F. M. 2007. Crop species and tillage effects on carbon sequestration in subsurface soil. Soil Sci. 172: 124-131.

Yang, X. M. and Wander, M. M. 1999. Tillage effects on soil organic carbon distribution and storage in a silt loam soil in Illinois. Soil Tillage Res. 52: 1-9.

Yang, X. and Kay, B. 2001a. Rotation and tillage effects on soil organic carbon sequestration in a typic Hapludalf in Southern Ontario. Soil Tillage Res. 59: 107-114.

Yang, X. and Kay, B. 2001b. Impacts of tillage practices on total, loose-and occluded-particulate, and humified organic carbon fractions in soils within a field in southern Ontario. Can. J. Soil Sci. 81: 149-156.

Yang, X. M., Drury, C. F., Wander, M. M. and Kay, B. D. 2008a. Evaluating the effect of tillage on carbon sequestration using the minimum detectable difference concept. Pedosphere 18: 421-430.

Yang, X., Drury, C., Reynolds, W. and Tan, C. 2008b. Impacts of long-term and recently imposed tillage practices on the vertical distribution of soil organic carbon. Soil Tillage Res. 100: $120-124$ 